\title{
Analysis of the sealing ability of different obturation techniques in oval-shaped canals: a study using a bacterial leakage model
}

\section{Análise da qualidade do selamento de diferentes técnicas de obturação em canais ovais: um estudo utilizando um modelo de infiltração bacteriana}

\author{
Gustavo De Deus* \\ Cristiana Francescutti Murad** \\ Claudia Mendonça Reis** \\ Eduardo Gurgel-Filho*** \\ Tauby Coutinho Filho****
}

\begin{abstract}
The aim of this study was to evaluate the sealing ability of 3 obturation techniques in oval canals using a bacterial leakage model. Seventy mandibular incisors with oval canals were selected after buccolingual and mesiodistal radiographs, and divided into three groups. After instrumentation, the canals were obturated respectively by lateral condensation (G1), warm vertical condensation (G2) and Thermafil (G3). Five root canals were not obturated and served as positive controls; five teeth with intact crowns served as negative controls. All teeth were mounted on a 2 chamber apparatus and then exposed to human saliva. The number of days required for the entire contamination of the root canals was recorded, observing the turbidity of the BHI broth, for a period of 100 days. $84.21 \%$ of the samples from the lateral condensation group (G1); $84.21 \%$ of the samples from the warm vertical condensation group (G2); and $89.47 \%$ of the samples from the Thermafil System group (G3) showed no contamination at the end of the study. No statistical significant difference was found among the three techniques. The quality of the apical seal in the three techniques tested was similar.
\end{abstract}

DESCRIPTORS: Root canal obturation; Dental leakage.

RESUMO: O objetivo deste estudo foi avaliar a qualidade do selamento obtido por 3 técnicas de obturação em canais ovais, através de um modelo de infiltração bacteriano. Setenta incisivos inferiores com canais ovais foram selecionados após radiografias bucolinguais e mésio-distais, e divididos em 3 grupos. Após a instrumentação, os dentes foram obturados respectivamente pela condensação lateral (G1), condensação vertical da guta-percha aquecida (G2) e pelo Thermafil (G3). Cinco canais radiculares que não foram obturados serviram como grupo controle positivo, e cinco com as coroas intactas serviram como grupo controle negativo. Todos os dentes foram montados em um aparato de 2 câmaras e expostos à saliva humana. O número de dias necessário à total contaminação do canal radicular foi verificado, através da observação do turvamento do BHI, por um período de 100 dias. Não apresentaram contaminação ao término do estudo 84,21\% das amostras do grupo da condensação lateral (G1); 84,21\% das amostras do grupo da condensação vertical da guta-percha aquecida (G2); e 89,47\% das amostras do grupo do Thermafil. Não houve diferença estatisticamente significativa entre as 3 técnicas. A qualidade do selamento apical nas 3 técnicas testadas foi similar.

DESCRITORES: Obturação do canal radicular; Infiltração dentária.

\section{INTRODUCTION}

The oval shape may make it difficult to clean properly and fill the root canal space ${ }^{14}$. Kersten et $a .^{4}$ (1986) reported that both the lateral condensation of gutta-percha cones as well as the vertical compacting of warm gutta-percha have been widely used in endodontic treatment, although their quality may differ in canals with different shapes ${ }^{4}$. Wu, Wesselink ${ }^{14}$ (2001) reported a high percentage of oval canals in the apical portion of human teeth roots $(\geq 50 \%)$ with the diameter of these oval canals tending to decrease apically. Both the irregular canal shape and inadequate biomechanical

\footnotetext{
* MSc, Department of Endodontics; **Specialists in Endodontics; ****PhD, Department of Endodontics - Rio de Janeiro State University.

*** PhD, Department of Endodontics, University of Fortaleza.
} 
Deus G, Murad CF, Reis CM, Gurgel-Filho E, Coutinho Filho T. Analysis of the sealing ability of different obturation techniques in oval-shaped canals: a study using a bacterial leakage model. Braz Oral Res 2006;20(1):64-9.

preparation may have negative influence on the filling quality. It could be postulated that irregularly-shaped canals may be filled more effectively by warm gutta-percha techniques, provided that they are clean ${ }^{13}$. Areas beyond the reach of the mechanical action of endodontic instruments in canals with irregular shapes can frequently be unfilled when the lateral condensation technique has been used ${ }^{13}$.

Researchers have evaluated the quality of the apical sealing using dye or radioisotope penetration, bacterial leakage, electrochemistry methods and through fluid transport. The method most frequently used is dye penetration. Despite its popularity, ease of use and the huge amount of studies on it, dye leakage has several negative aspects ${ }^{15}$ that allow a high variety of results from similar experiments. This methodological model is subjective, less comparative, with a low reproduction capacity and lack of reliable statistical results. Studies that use bacterial tracer derived from specific cultures or from the human saliva are considered to be more conspicuous than the tests with dye ${ }^{10}$.

The purpose of this work was to compare the sealing ability of the lateral condensation of guttapercha cones, the vertical compacting of warm gutta-percha and the Thermafil System techniques in irregularly-shaped canals.

\section{MATERIALS \& METHODS}

\section{Tooth selection and classification of root canals}

One hundred and eighty mandibular incisors were selected from the tooth bank of the Rio de Janeiro State University, and radiographs were taken in the buccolingual and mesiodistal directions to select only the teeth with a single oval root canal. Teeth with oval canals were selected only when the long:short diameter ratio was $\geq 2.5$ at $5 \mathrm{~mm}$ from the apex. All teeth that presented isthmus, lateral canals, accessory canals or two canals were excluded from the study. Therefore only 70 incisors were classified as having oval canals.

\section{Instrumentation}

Standard access cavities were made and all the canal orifices were located. The patency of each canal was confirmed by inserting a \#15-Kfile through the apical foramen (AF) and the working length was determined by subtracting $1 \mathrm{~mm}$ from the length up to the apex. The coronal and middle thirds of each canal were flared using Gates Glidden drills (Dentsply-Maillefer Instruments SA, Ballaigues, Switzerland), sizes \#4, \#3 and \#2. The apical third was prepared with Flexofiles ${ }^{\circledR}$ sizes \#40, \#35, \#30 and \#25 (25 mm - Dentsply-Maillefer Instruments SA, Ballaigues, Switzerland) respectively. During instrumentation, the canals were irrigated with freshly prepared $5.25 \% \mathrm{NaOCl}$ (Fórmula \& Ação Ltda., São Paulo, SP, Brazil) and a final flush of 17\% EDTA (pH 7.7, Fórmula \& Ação Ltda., São Paulo, SP, Brazil) for 5 minutes. The canals were dried with paper points (Dentsply-Maillefer Instruments SA, Ballaigues, Switzerland).

\section{Obturation}

Sixty of the prepared teeth were randomly divided into three equal groups $(n=20)$. Five teeth with intact crowns served as negative controls and five teeth that were not obturated served as positive controls. The teeth were obturated using the Grossman sealer (Endofill, Herpo Prod. Dent. LTDA., Petrópolis, RJ, Brazil) and the Lateral Condensation Technique (G1), the Warm Vertical Condensation Technique (G2) or the Thermafil System (G3).

In G1, a \#25 master gutta-percha cone (Endopoints Ind.\&Com. LTDA., Paraíba do Sul, RJ, Brazil) was placed in the canal with sealer up to the working length. Lateral compaction was achieved in each canal by using 6 fine-medium accessory gutta-percha cones and endodontic finger spreader \#30 (Dentsply-Maillefer Instruments SA, Ballaigues, Switzerland). A heated instrument was used to remove the excess guttapercha.

The Schilder technique was used in G2. In G2 a medium sized non-standardized gutta-percha cone was used as a master cone with a \#25 tip size. The cone was placed in the canal with sealer up to the full working length. A medium sized plugger was prefitted to its binding point, which was $5 \mathrm{~mm}$ short of the working length. The heat carrier Touch'n Heat connected with the plugger (Kerr/Analytic Endodontics, Glendora, CA, USA) was driven through the master cone, plasticizing the gutta-percha. It was then withdrawn from the canal, removing increments of gutta-percha, followed by a cold vertical condensation ${ }^{8}$. This procedure was done three times until it reached the binding point. The backfilling was made with 
Deus G, Murad CF, Reis CM, Gurgel-Filho E, Coutinho Filho T. Analysis of the sealing ability of different obturation techniques in oval-shaped canals: a study using a bacterial leakage model. Braz Oral Res 2006;20(1):64-9.

the Obtura II System (Obtura Corp., Fenton, MO. USA).

In G3, a \#25 plastic Thermafil Obturator (Tulsa Dental Products, Tulsa, OK, USA) was heated in a Termaprep Oven (Tulsa Dental Products, Tulsa, OK, USA), according to the manufacturer's instructions and Johnson ${ }^{3}$ (1978), and it was inserted into the root canal, with sealer, with firm apical pressure up to the working length. A round diamond bur in a turbine handpiece was used to cut the plastic shaft at 1-2 $\mathrm{mm}$ within the access cavity. The gutta-percha was condensed with slight apical pressure.

All roots were sectioned at $10 \mathrm{~mm}$ from the apex, with a diamond disc, and were stored in $100 \%$ humidity at $37^{\circ} \mathrm{C}$ for 14 days, for total cure of the sealer.

\section{Preparation of samples and the bacterial leakage apparatus}

Two coats of nail varnish were applied on the external surface of all teeth, except for $2 \mathrm{~mm}$ around the apical foramen, in order to prevent bacterial leakage through lateral canals or other discontinuities in the cementum. All roots were inserted in $1.5 \mathrm{ml}$ eppendorf plastic tubes (Elkay, Shrewbury, MA, USA). The joint tooth/eppendorf was adapted, under pressure, in a rubber cover (the cover of a bottle of penicillin), which was cut smaller, so it became small enough to enter inside the glass flask, aiming to achieve a better marginal sealing of the system. The intersection of the root, the eppendorf and the rubber was sealed with cyanoacrylate adhesive (Loctite 496, Henkel Ltda, São Paulo, SP, Brazil). The system was sterilized overnight using ethylene oxide gas, and then placed in a $9 \mathrm{ml}$ sterilized glass flask containing $4 \mathrm{ml}$ of sterile Brain Heart Infusion broth (BHI - Oxoid LTD., Wade Road, Basingstoke, Hanks, UK), so that about $2 \mathrm{~mm}$ of the root apex was immersed in the broth. The external limit of the apparatus was sealed with cyanoacrylate and Parafilm M (Laboratory Film, American National Can, Chicago Illinois, USA) (Figure 1). To verify sterilization, the whole apparatus was incubated at $37^{\circ} \mathrm{C}$ for 7 days. Two samples were contaminated, therefore the samples were eliminated from their groups, leaving each group with 19 teeth.

Afterwards, the reservoir (eppendorf) of each whole apparatus was filled with human saliva mixed in BHI broth in a $1: 1(\mathrm{v} / \mathrm{v})$ ratio. The saliva was collected from only one individual and

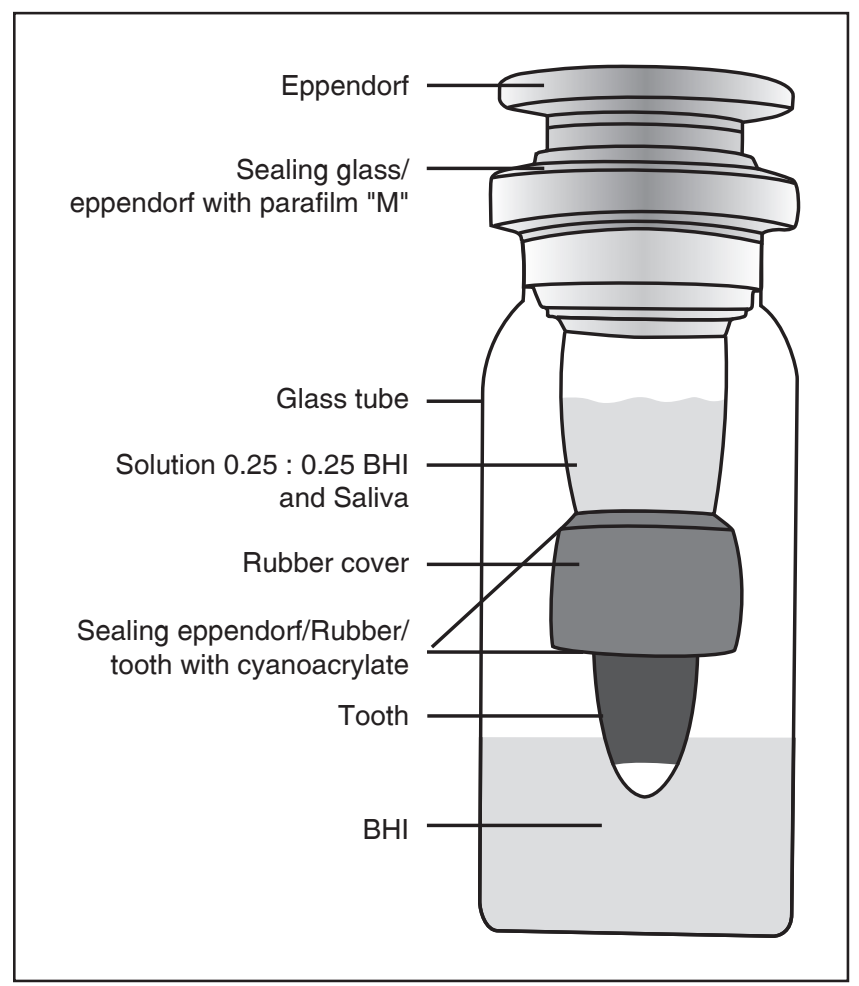

FIGURE 1 - Setup of the model design.

completely replenished every 3 days. The whole apparatus was incubated at $37^{\circ} \mathrm{C}$ and checked every 3 days for the appearance of turbidity in the BHI broth during the following 100 days. The data obtained were statistically analyzed for number of infiltrated samples through time of exposure to bacterial source.

\section{Checking the oval canals}

Each sample was embedded in an epoxy resin cylinder (Arazyn 1.0, Ara Química, SP, Brazil), using a silicone mould ( $0.25 \times 0.20$ inches) as matrix to facilitate manipulation. Subsequently, the samples were sectioned horizontally $5 \mathrm{~mm}$ from the apex, using a low-speed saw (Isomet, Buhler Ltd., Lake Bluff, NY, USA) with a diamond disc $(\varnothing 125 \mathrm{~mm} \times 0.35 \mathrm{~mm} \times 12.7 \mathrm{~mm}-330 \mathrm{C})$, with continuous water irrigation. After the polishing process, digital images of the samples were captured using magnifications ranging from $10 \mathrm{X}$ to $20 \mathrm{X}$ under a light microscope Axioplan 2 (Carl Zeiss, Hallbergmoos, Germany). The sample sectioning was made solely with the purpose of verifying the methodology used to classify the teeth as oval or round. 
Deus G, Murad CF, Reis CM, Gurgel-Filho E, Coutinho Filho T. Analysis of the sealing ability of different obturation techniques in oval-shaped canals: a study using a bacterial leakage model. Braz Oral Res 2006;20(1):64-9.

TABLE 1 - Accumulated probability of infiltrated cases per week.

\begin{tabular}{l|c|c|c|c|c|c|c|c|c|c|c|c|c|c|c|c}
\hline \hline Weeks & 1 & 2 & 3 & 4 & 5 & 6 & 7 & 8 & 9 & 10 & 11 & 12 & 13 & 14 & 15 & Total \\
\hline Lateral condensation & 0 & 0 & 0 & 1 & 0 & 0 & 0 & 0 & 0 & 1 & 0 & 0 & 0 & 0 & 1 & 3 \\
\hline Schilder & 0 & 0 & 0 & 0 & 0 & 0 & 0 & 0 & 1 & 0 & 2 & 0 & 0 & 0 & 0 & 3 \\
\hline Thermafil & 0 & 0 & 0 & 0 & 0 & 0 & 0 & 0 & 1 & 0 & 0 & 1 & 0 & 0 & 0 & 2 \\
\hline \hline
\end{tabular}

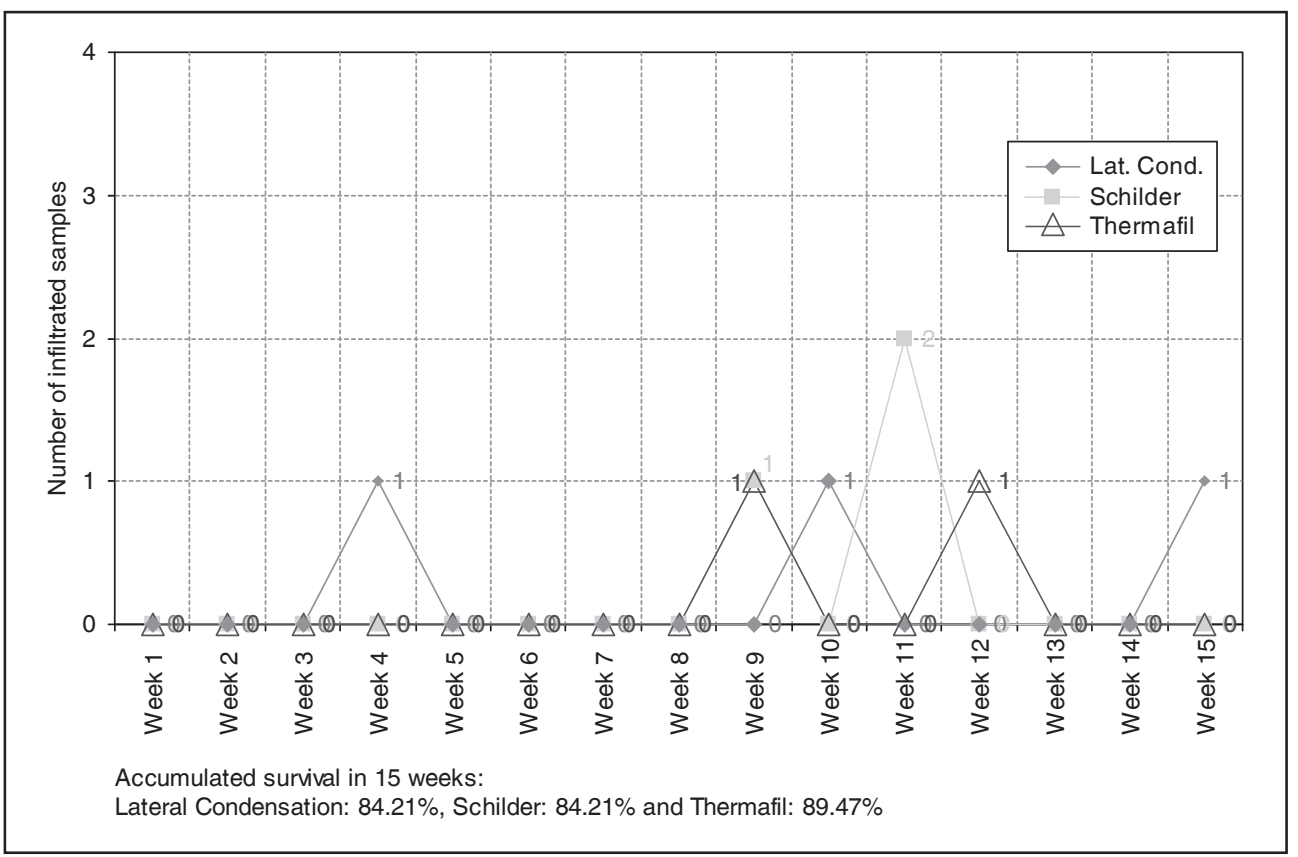

GRAPH 1 - Pattern of leakage in the experimental groups.

\section{RESULTS}

One hundred percent of the negative control group showed no contamination during the study, and all specimens of the positive control group showed broth turbidity within the $3^{\text {rd }}$ day of incubation. After 100 days of research, $84.21 \%$ of the samples from the lateral condensation group (G1); $84.21 \%$ of the samples from the warm vertical condensation group (G2); and $89.47 \%$ of the samples from the Thermafil System group (G3) showed no contamination.

Leakage in the experimental group was first observed at the $25^{\text {th }}$ day of incubation and ranged from 25 to 99 days. Only 3 of the 19 samples in the lateral condensation group (G1) and in the warm vertical condensation group (G2) showed total contamination of the BHI broth. Two of the 19 samples of the Thermafil System group (G3) presented leakage. The data are shown in Table 1. The Kaplan-Meier test showed that there was no significant statistical difference among the three techniques tested $(\mathrm{P}>.05)$. The statistical analysis was done per week. These results are plotted in Graph 1.

The images of all sectioned samples confirmed the irregular shapes of the canals and are shown in Figures 2 and 3. Gutta-percha and sealer did not penetrate through the entire extension of the canal in $87 \%$ of the cases.

\section{DISCUSSION}

Dye leakage studies have been, for many years, the most common method used to evaluate the quality of root canal fillings; however, the reliability of those results has been questioned ${ }^{11,12}$. Therefore, many leakage studies using bacterial cultures or human saliva have been widely used to test the sealing quality of endodontic filling materials because they might be more meaningful and provide more precise and reproducible data ${ }^{11,12}$. This method may be considered more suitable for the clinical situation particularly because it uses human saliva as a bacterial source. This is advantageous because it closely simulates the real clinical 
Deus G, Murad CF, Reis CM, Gurgel-Filho E, Coutinho Filho T. Analysis of the sealing ability of different obturation techniques in oval-shaped canals: a study using a bacterial leakage model. Braz Oral Res 2006;20(1):64-9.

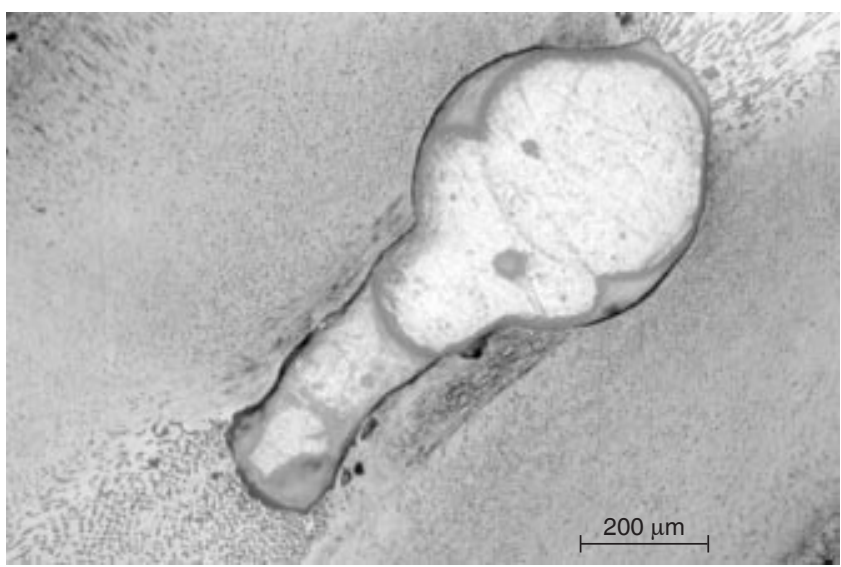

FIGURE 2 - Cross section of the root canal space confirms its irregular shape (G1 - Lateral Condensation).

situation regarding the relation between the tooth and the oral flora, but the in vitro results can not be generalized to the clinical situation. The method also allows an evaluation of the samples after specific periods of time and it preserves the sample ${ }^{9,10}$. Nevertheless, it uses a static model that does not simulate the exact clinical conditions, it requires long periods of observation and does not allow the quantification of the penetrating bacteria ${ }^{10}$.

Mandibular incisors with single oval canals were used with the purpose of evaluating the quality of the root canal sealing in canals in which the anatomic difficulty could lead to a higher degree of failure. The studies of Pucci, Reig ${ }^{6}$ (1944) and of Mauger et al. ${ }^{5}$ (1998) reported the anatomic variety of those teeth. Teeth with oval canals were selected only when the long:short diameter ratio of a canal was $\geq 2.5$ at $5 \mathrm{~mm}$ from the apex ${ }^{5,13,14}$, using the radiographic method ${ }^{5}$.

Previous researches have compared bacterial leakage in different obturation techniques. Jacobson et al. ${ }^{2}$ (2002) related that the coronal leakage occurs more quickly using the lateral condensation technique than with the continuous wave of condensation, however there was no statistical difference between the groups. Gilbert et al. ${ }^{1}$ (2001) compared bacterial and India ink leakage and observed that vertical compaction leaked significantly less than lateral compaction and Thermafil during bacterial challenge. Dye leakage showed no statistically significant difference between the 3 techniques, showing that bacterial leakage and dye leakage demonstrated considerable variability. Wu et al. ${ }^{13}$ (2001) reported that there was no statistically significant difference between lateral condensation and warm vertical compaction, however the

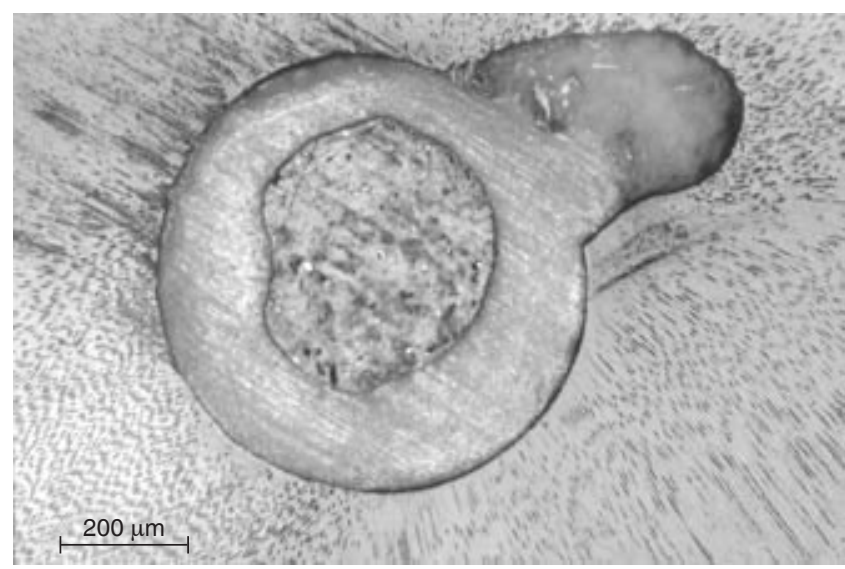

FIGURE 3 - Cross section of the root canal space confirms its irregular shape (G3 - Thermafil).

percentage of gutta-percha-filled canal area was greater using the warm gutta-percha technique than that of the cold gutta-percha technique in oval canals.

Our results demonstrated that at the end of 100 days, the contamination was extremely small in all groups. Ricucci, Bergenholtz ${ }^{7}$ (2003) related that well-prepared and filled canals resist bacterial penetration even when directly exposed to the oral environment. Contrasting with these results, Siqueira et al. ${ }^{9}$ (2000) demonstrated that there was no statistical difference between continuous wave of condensation, Thermafil and lateral condensation in a bacterial leakage study, but there was a high percentage of contamination of the samples.

These results agree with those of several leakage studies which evaluated the quality of root canal fillings after different filling techniques ${ }^{2,9,13}$. On the other hand, they disagree with those of most studies in relation to bacterial penetration in obturated teeth without coronal seal. In those reports, the lack of the temporary coronal restoration was considered the predicted factor of failure more important than the endodontic filling itself $f^{9,11}$. This study does not suggest that the quality of the temporary seal is insignificant for the outcome of the endodontic treatment, even though the number of the contaminated samples was very small, and the selected teeth had oval canals which create difficulty for the sealing ability of the techniques. However the quality of the gutta-percha filling is an important factor in preventing bacterial coronal penetration. On the other hand, bacteria left in the uninstrumented/unfilled areas may be able to recolonize the canals with time, causing failure of the endodontic treatment. 
Deus G, Murad CF, Reis CM, Gurgel-Filho E, Coutinho Filho T. Analysis of the sealing ability of different obturation techniques in oval-shaped canals: a study using a bacterial leakage model. Braz Oral Res 2006;20(1):64-9.

\section{CONCLUSION}

It is concluded that the quality of the apical sealing in the three techniques tested was similar, even after pre-selecting oval canals which could

\section{REFERENCES}

1. Gilbert SD, Whiterspoon DE, Berry CW. Coronal leakage following three obturation techniques. Int Endod J 2001; 34(4):293-9.

2. Jacobson HL, Xia T, Baumgartner, JC, Marshall G, Beeler WJ. Microbial leakage evaluation of the continuous wave of condensation. J Endod 2002;28(4):269-71.

3. Johnson WB. A new gutta-percha technique. J Endod 1978;4(6):184-8.

4. Kersten HW, Fransman R, Thoden van Velzen SK. Thermomechanical compaction of gutta-percha. Part II. A comparison with lateral condensation in curved root canals. Int Endod J 1986;19(3):134-40.

5. Mauger MJ, Schindler WG, Walker WA. An evaluation of canal morphology at different levels of root resection in mandibular incisors. J Endod 1998;24(9):607-9.

6. Pucci FM, Reig R. Conductos radiculares. Montevideo: Editorial Médico-Quirurgica; 1944.

7. Ricucci D, Bergenholtz G. Bacterial status in root filled teeth exposed to the oral environment by loss of restoration and fracture or caries - a histological study of treated cases. Int Endod J 2003;36(11):787-802.

8. Schilder H. Filling root canal in three dimensions. Dent Clin North Am 1967;723-44. create difficulty for the complete filling of the root canal space. The absence of a temporary coronal seal did not contribute to obtain a high number of leakage samples.

9. Siqueira Jr JF, Rôças IN, Favieri A, Abad EC, Castro AJR Gahyva SM. Bacterial leakage in coronally unsealed root canals obturated with three different techniques. Oral Surg Oral Med Oral Pathol Oral Radiol Endod 2000;90(5):64750 .

10. Siqueira Jr JF, Rôças IN, Lopes HP, De Uzeda M. Coronal leakage of two root canal sealers containing calcium hydroxide after exposure to human saliva. J Endod 1999;25(1):14-6.

11. Torabinejad M, Ung B, Kettering JD. In vitro bacterial penetration of coronally unsealed endodontically treated teeth. J Endod 1990;16(12):566-9.

12. Wu MK, De Gee AJ, Wessilink PR, Moorer WR. Fluid transport and bacterial penetration along root canal fillings. Int Endod J 1993;26(4):203-8.

13. Wu MK, Kast'Akova A, Wessilink PR. Quality of cold warm gutta-percha fillings in oval canals in mandibular premolars. Int Endod J 2001;34(6):485-91.

14. Wu MK, Wesselink PR. A primary observation on the preparation and obturation of oval canals. Int Endod $\mathrm{J}$ 2001;34(2):137-41.

15. Wu MK, Wesselink PR. Endodontic leakage studies reconsidered. Part I. Methodology, application and relevance. Int Endod J 1993;26(1):37-43. 